\title{
Lasarus, lasarett og lasaron
}

\author{
Navnet Lasarus i Bibelen sto for sykdom og fattigdom og er opphav til ordene lasarett og lasaron. \\ I våre dager brukes disse betegnelsene sjelden.
}

«Det var en rik mann som kledde seg i purpur og fineste lin og levde i fest og luksus dag etter dag. Men utenfor porten hans lå det en fattig mann som het Lasarus, full av verkende sår. Han ønsket bare å få mette seg med det som falt fra den rikes bord. Hundene kom til og med og slikket sårene hans.» Slik begynner liknelsen om den rike mannen og Lasarus (1). Det gikk til slutt godt med ham, slik også navnet hans bærer bud om. Lasarus er identisk med det hebraiske Eleazar, som betyr «han som Gud hjelper» (2). Men det er lite i historien som bringer tankene i retning av lasaretter. Hvordan kan det henge sammen?

\section{Lasarett}

Det eldste lasarett vi kjenner ble opprettet på begynnelsen av 1400-tallet utenfor Venezia på øya Isola di Santa Maria di Nazareth (Santa Maria av Nasarets øy) $(3,4)$. Der lå et karantenesykehus for pestsyke. Nettopp i Venezia, som hadde en livlig sjøforbindelse til Orienten, var det stort behov for et slikt sykehus. Ut fra navnet på øya dannet man ordet nazzaretto som betegnelse for sykehuset. Først senere ble begynnelsesbokstaven $\mathrm{n}$ byttet ut med 1 , og her er det at Lasarus kommer inn i bildet. Utskiftningen av n med 1 er sannsynligvis skjedd ved en sammenblanding med det bibelske navnet Lasarus, som kunne brukes om både syke og fattige mennesker (3).

Det er trolig bakgrunnen til lazzaretto eller lazzeretto som det heter på italiensk i dag. Det er derfra vi, som andre europeiske språk, har fått ordet lasarett.

Ordets betydningsutvikling må ses i lys av hospitalenes historie. Sykehusene i middelalderen var nærmest beregnet på leprasyke, og Lasarus ble i mange språk betegnelse for spedalske (2). Vi ser det også på engelsk, der lazar ble brukt allerede på 1300-tallet om enhver fattig og syk person, men særlig om leprasyke $(4,5)$. Fra 1500 og 1600-tallet fikk man formene lazaretto, lazaret og lazar-house med samme betydninger $(4,5)$.

På norsk kunne man tidligere også bruke lasarett $\mathrm{i}$ betydningen hospital, sykehus. Henrik Wergeland (1808-45) skrev om «et lazareth for alskens inkurable» (6). I dag brukes det ikke lenger på denne måten. Lasarett har fått et spesielt bruksområde, nemlig om midlertidige behandlingssteder for syke eller sårede for å dekke ekstraordi- nære behov, som ved krig og katastrofer. Man kan snakke om feltlasarett og epidemilasarett (7). Riksmålsordboken angir en rekke sammensetninger med dette ordet, slik som lasarettfeber (= flekktyfus), lasarettlege, lasarettskip, lasarett-tog og lasarettvogn (8).

Men også denne mer begrensede betydningen av lasarett ser ut til å bli mindre vanlig. Nå brukes «sykehus» som regel også i denne sammenhengen. Vi sier heller feltsykehus enn feltlasarett (9).

\section{Lasaron}

Lasarus kunne altså brukes som betegnelse på både syke og fattige mennesker, som vel rimelig var, ettersom opphavsmannen var både syk og fattig. I sitatordbøker er det bare den fattige mannen som har gitt avtrykk: Fattig som Lasarus, heter det (10). Her ligger også opphavet til lazzarone, som er det italienske ordet for tigger eller dagdriver. På norsk heter det lasaron. Men også dette ordet brukes lite $(11,12)$. Nå snakker vi heller om tiggere (12).

\section{Andre lasaruser}

I Bibelen finnes også en annen, og mer berømt, Lasarus: Mannen som Jesus vekket opp fra de døde (Joh 11) (13). Også den oppstandne Lasarus har gitt opphav til begreper som er blitt brukt i ulike medisinske sammenhenger (14). En av dem er lasarussyndromet som betegnelse på psykiske plager som kan oppstå etter å ha overlevd hjertestans (15). Men disse bruksområdene er mer tilfeldige og uklare.

\section{Erlend Hem}

erlend.hem@medisin.uio.no

Tidsskriftet

Erlend Hem (f.1970) er dr.med. og assisterende redaktør i Tidsskriftet.

\section{Litteratur}

1. Luk 16,19-31. Bibelen 2011. www.bibel.no/ Hovedmeny/Nettbibelen.aspx?book=LUK\& chapter $=16$ \&verse $=20(10.12 .2011)$

2. Falk H, Torp A. Etymologisk ordbog over det norske og det danske sprog. Oslo: Bjørn Ringstrøms antikvariat, 1991. Faksimileutg. Originalutg. Kristiania: Aschehoug 1903-06: 446

3. Jacobsen $H G$, Jensen $H$, Jørgensen PS. Politikens ord med historie. København: Politikens forlag, 1994: 144

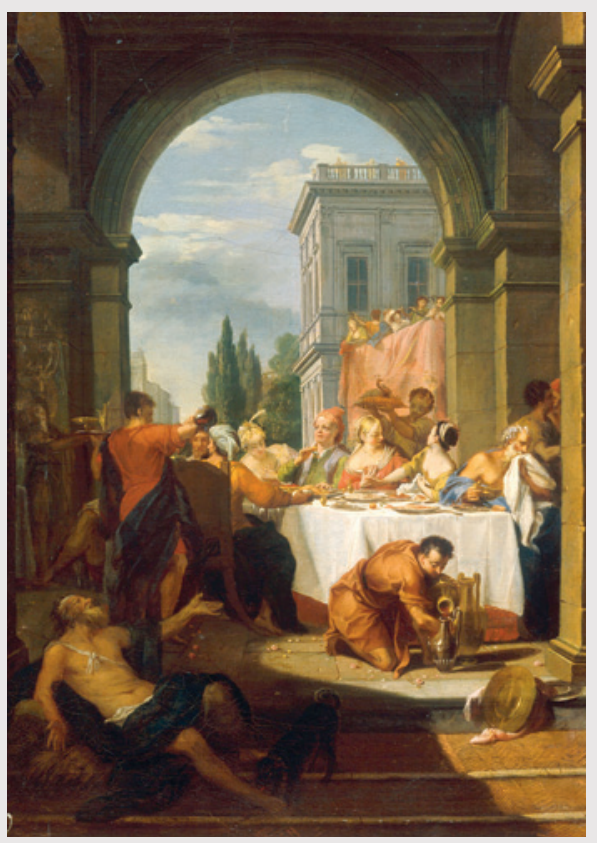

Lasarus ble av den katolske kirke betraktet som skytshelgen for de syke, særlig de spedalske. Den rike mannen og Lasarus (1704) av Nicolas Vleughels (1668-1737). Foto akg-images/Scanpix

4. Fortuine R. The words of medicine: sources, meanings, and delights. Springfield, Ill.: Charles C. Thomas, 2001: 227

5. Lazar, lazaret, lazaretto, lazar-house. Oxford English Dictionary. http://oed.com/view/ENtry/ 106537, http://oed.com/view/ENtry/1065439, http://oed.com/view/ENtry/106540, http://oed.com/view/ENtry/106541 (10.12.2011).

6. Noreng H. Norsk riksmålsordbok. Bd. 6. Oslo: Kunnskapsforlaget, 1995: 1673.

7. Lasarett. I: Bokmålsordboka og Nynorskordboka. www.nob-ordbok.uio.no/perl/ordbok.cgi?OPP= lasarett (10.12.2011).

8. Knudsen T. Sommerfelt A. Norsk riksmålsordbok Bd. 2. Oslo: Kunnskapsforlaget, 1983: 2879.

. Feltlasarett. I: Store norske leksikon. http://snl.no/feltlasarett (10.12.2011)

10. Evensberget S, Gundersen D. Bevingede ord: ordtak, sitater og deres opprinnelse. 4. utg. Oslo: Kunnskapsforlaget, 2006: 144

11. Skår A. Utrydningstruede ord, 1. Oslo: Messel for lag, 2004: 68-9.

12. Schjerven PWB. Nostalgisk ordbok. Oslo: Vega forlag, 2010: 183.

13. Haubrich WS. Medical meanings: a glossary of word origins. Philadelphia, PA.: American College of Physicians, 1997: 123.

14. Adhiyaman V, Adhiyaman S, Sundaram R. The Lazarus phenomenon. J R Soc Med 2007; 100: 552 - 7. www.ncbi.nlm.nih.gov/pmc/articles/ PMC2121643 (10.12.2011).

15. Jablonski S. Jablonski's dictionary of syndromes and eponymic diseases. 2. utg. Malabar, Fla. Krieger Publ., 1991: 357 